\title{
Frequency of the exon 3-deleted/full-length growth hormone receptor polymorphism in Saudi Arabian population
}

\author{
Yahia A. Kaabi, $M S c$, PhD.
}

$$
\begin{aligned}
& \text { ABSTRACT }
\end{aligned}
$$

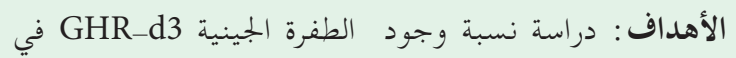

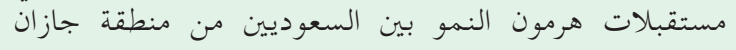

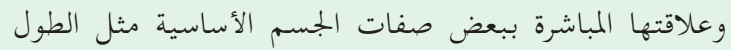

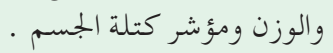

$$
\begin{aligned}
& \text { الطريقة : أجريت هذه الدراسة في الفترة من يناير الى ابريل للعام }
\end{aligned}
$$

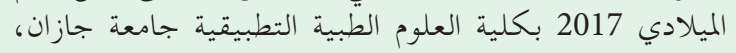

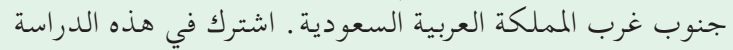

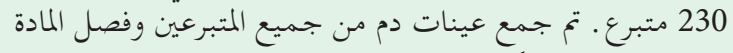

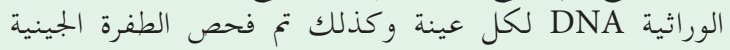

$$
\begin{aligned}
& \text {. Multiplex_PCR بإِتخدام تقنية وكنية GHR_d3 }
\end{aligned}
$$

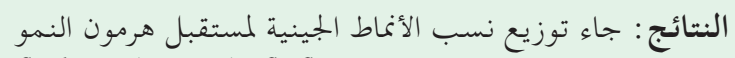

$$
\begin{aligned}
& \text { (GHR) }
\end{aligned}
$$

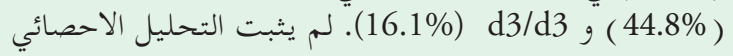

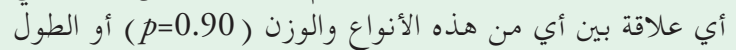

$$
\begin{aligned}
& \text { (p=0.12) أو مؤشر كتلة الجسم ( } \\
& \text { الخاتمة : أوجدات الدراسة للمرة الأولى نسبة وجود الطفرة الجينية }
\end{aligned}
$$

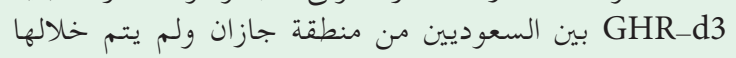

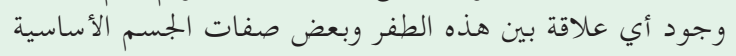

$$
\begin{aligned}
& \text { مثل الوزن أو الطول أو مؤشر كتلة الجسمس. }
\end{aligned}
$$

Objectives: To investigate the frequency of the growth hormone receptor (GHR)-d3 polymorphism in a random sample of Saudi Arabian population from Jazan province, and test the effects of the polymorphism on some anthropometric factors.

Methods: This cross-sectional population-based study was conducted during the period from January to April 2017 at the College of Applied Medical Sciences, Jazan University, Southwestern Saudi Arabia. A total of 230 healthy adult male and female volunteers were randomly recruited. Genomic DNA was extracted from the whole blood, and the GHR exon 3 locus was genotyped using multiplex polymerase chain reaction.

Results: The distributions of the GHR genotypes were as follows: $\mathrm{fl} / \mathrm{fl}(39.1 \%), \mathrm{fl} / \mathrm{d} 3(44.8 \%)$, and $\mathrm{d} 3 / \mathrm{d} 3$ $(16.1 \%)$. No statistically significant differences were found between $\mathrm{f} / \mathrm{f}, \mathrm{f} / \mathrm{d} 3$, or $\mathrm{d} 3 / \mathrm{d} 3$ GHR genotypes in terms of weight $(p=0.90)$, height $(p=0.12)$, or body mass index (BMI) $(p=0.83)$ values.

Conclusion: No correlations were found between the GHR-d3 polymorphism and weight, height, or BMI.

$$
\text { Saudi Med J 2017; Vol. } 38 \text { (11): 1090-1095 }
$$
doi: 10.15537/smj.2017.11.21109

From the Department of Medical Laboratory Technology, College of Applied Medical Sciences, Jazan University, Jazan, Kingdom of Saudi Arabia.

Received 15th May 2017. Accepted 25th July 2017.

Address correspondence and reprint request to: Dr. Yahia A. Kaabi, Assistant Professor (Clinical Chemistry), Department of Medical Laboratory Technology, College of Applied Medical Sciences, Jazan University, Jazan, KingdomofSaudi Arabia.E-mail:ykaabi@jazanu.edu.sa ORCID ID: orcid.org/0000-0001-5418-5782.

$\mathrm{H}$ uman growth hormone ( $\mathrm{hGH}$; somatotropin) is a peptide hormone synthesized in the adenohypophysis to promote growth-related cellular responses. ${ }^{1}$ Human growth hormone signaling is transduced by growth hormone receptor (GHR), which belongs to type I cytokine receptor superfamily. ${ }^{2}$ Full-length GHR is encoded by 9 exons located on the short arm of chromosome 5, region 5p13-p12. ${ }^{3}$ Exons 3-9 are translated into full-length GHR, which is a single pass transmembrane protein composed of 246 amino acid residues for the extracellular domain and short transmembrane domain and 350 amino acids residues for the intracellular domain. ${ }^{3}$ Deletion of exon 
3 from the GHR gene (GHR-d3) is a common humanspecific polymorphism that occurred several million years ago as a result of homologous recombination. ${ }^{4}$ This results in 3 possible GHR gene allelic variants: $\mathrm{f} / \mathrm{fl}$, in which both alleles have the full-length copy of the GHR gene; $\mathrm{fl} / \mathrm{d} 3$, in which one allele carries the full-length copy and the other carries the exon 3 deletion mutation; and $\mathrm{d} 3 / \mathrm{d} 3$, in which both alleles carry the exon 3 deletion mutation. Deletion of exon 3 results in elimination of 23 amino acids from the GHR extracellular domain, which influences GHR membrane trafficking and stability, but does not alter the GH/GHR interaction. ${ }^{5,6}$ The clinical relevance of the GHR-d3 polymorphism remains controversial. In a meta-analysis study, a modest association between the GHR-d3 gene and increased responsiveness to exogenous recombinant human $\mathrm{GH}(\mathrm{rhGH})$ therapy in short children with GH deficiency, small for gestation age (SGA), or Turner syndrome has been reported, ${ }^{7}$ although some studies have reported that there is no association. ${ }^{8,9}$ The GHR-d3 polymorphism has also been shown to influence the body composition under some conditions. For example, this polymorphism has been linked to increased insulin secretion and higher triglyceride levels in normal individuals at puberty. ${ }^{10}$ Associations with increased body mass index (BMI) and insulin resistance have been reported in acromegalic patients. ${ }^{11,12}$ In contrast, the GHR-d3 polymorphism was found to be associated with lower BMI in obese children ${ }^{13}$ and in girls with Turner syndrome. ${ }^{14}$ Some studies have also reported a potential impact of the GHR-d3 genotype on height. ${ }^{15,16}$ Kang et al ${ }^{15}$ reported an association between the GHR-d3 polymorphism and mandibular bone height. A study in a population of Greek children ${ }^{17}$ reported a significant height gain and growth velocity in GHR-d3 carriers who received rhGH therapy for one year.

The aim of this work was to investigate the prevalence of different GHR genotypes among the Saudi Arabian population and evaluate the influence of such polymorphisms on weight, final height, and BMI.

Methods. This was a cross-sectional study involving 230 healthy Saudi Arabian volunteers (144 men and

Disclosure. Authors have no conflict of interests, and the work was not supported or funded by any drug company.
86 women) from Jazan province. The individuals were recruited from the College of Applied Medical Sciences, Jazan University, southwestern Saudi Arabia, between January and April 2017. The inclusion criteria were as follows: Saudi Arabian citizens from Jazan Province and age between 20 and 45 years. The exclusion criteria were as follows: history of obesity, growth-related disorders, or chronic diseases.

All participants were asked to read and sign an informed consent form. The study was approved by the research ethical committee of King Fahd Central Hospital in Jazan. Before blood sample collection, demographic data, including gender, age, weight, and height, were collected. The BMI was calculated from weight in kilograms $(\mathrm{kg})$ and height in meters $(\mathrm{m})$ according to the formula: $\mathrm{BMI}=$ weigh $(\mathrm{kg}) /$ height $(\mathrm{m})^{2}$.

Blood collection and DNA extraction. Whole-blood samples were collected from each subject in 5-mL ethylenediaminetetraacetic acid vacutainer tubes using an aseptic phlebotomy technique. For genomic DNA extraction, $200 \mu \mathrm{L}$ of the collected blood samples was applied to an Illustra Blood Genomic Prep Mini Spin Kit (GE Healthcare Life Sciences Ltd., UK), according to the manufacturer's instructions.

Genotyping. The full-length GHR allele (f) and exon 3-deleted GHR allele (d3) were detected by multiplex polymerase chain reaction (PCR). Approximately $10 \mathrm{ng}$ of the extracted DNA was used as a template for PCR with previously reported primers, as follows: (G1) forward primer, 5'-TGTGCTGGTCTGTTGGTCTG-3', (G2) reverse primer, 5'-AGTCGTTCCTGGGACAGAGA-3', and (G3) reverse primer, 5' - CCTGGATTAACACTTTGCAGACTC-3' (GenBank accession no. AF155912). Polymerase chain reaction was carried out with a final volume of $25 \mu \mathrm{L}$. The reaction mixture contained $1 \mu \mathrm{L}$ DNA, $1 \mu \mathrm{L}$ of each primer, $8.5 \mu \mathrm{L}$ sterile nuclease-free deionized distilled water, and $12.5 \mu \mathrm{L}$ of $2 \times$ Top Taq Master Mix (Qiagen, Germany). The thermal protocol for PCR was as follows: initial denaturation for $4 \mathrm{~min}$ at $94^{\circ} \mathrm{C}$ followed by 35 cycles of 30 seconds of denaturation at $94^{\circ} \mathrm{C}, 30$ seconds of annealing at $57^{\circ} \mathrm{C}$, and 45 seconds of elongation at $72^{\circ} \mathrm{C}$. After the cycles, a final extension step was carried out at $72^{\circ} \mathrm{C}$ for $10 \mathrm{~min}$. The PCR products were then run on $1 \%$ agarose gel and stained with ethidium bromide for DNA visualization and imaging. The $\mathrm{fl}$ allele was represented by a 935-bp fragment, and the d3 allele was represented by a 532-bp fragment on the agarose gel. The homozygous full-length genotype (fl/f) 
was indicated by the presence of a single band at $935 \mathrm{bp}$, whereas the homozygous exon 3-deleted genotype (d3/ d3) was indicate by the presence of a single band at 532 bp. Heterozygous carriers of the full-length and exon 3 -deleted genotype $(\mathrm{f} / \mathrm{d} 3)$ were represented by the presence of 2 bands at 935 and $532 \mathrm{bp}$ on the agarose gel (Figure 1).

Statistical analysis. Hardy-Weinberg equilibrium (HWE) between the observed and expected GHR genotype frequencies was calculated using Chi-squared $\left(\chi^{2}\right)$ tests. Anthropometric data were expressed as percentages or means \pm standard deviations (SDs). Height, weight, and BMI were first transformed into SD scores (SDSs) according to age- and gender-matched national standards. Comparisons between means of different GHR genotypes were carried out using one-way analysis of variance (ANOVA). Differences were considered statistically significant if the $P$ value was less than 0.05. All statistical analyses were conducted using GraphPad Prism software (San Diego, CA, USA).

Results. The distribution of all GHR genotypes in the present study were in Hardy-Weinberg equilibrium (Table 1). Analysis of the distribution of the GHR genotypes in the total study population showed that $39.1 \%$ of subjects carried the $\mathrm{f} / \mathrm{fl}$ genotype, $44.8 \%$ carried the $\mathrm{f} / \mathrm{d} 3$ genotype, and $16.1 \%$ carried the $\mathrm{d} 3 / \mathrm{d} 3$ genotype (Table 2). Single allele frequencies were 61.5\% for $\mathrm{fl}$ and $38.5 \%$ for $\mathrm{d} 3$ allele. Analysis of variance showed that there were no significant differences in weight, height, and BMI SDSs across different GHR genotypes ( $p=0.90, p=0.12$, and $p=0.83$ ).

Discussion. Growth hormone receptor-d3 is a common polymorphism in humans and has been found to alter responses to rhGH therapy in GH-deficient patients and to affect newborn infant size, glucose metabolism, and BMI. ${ }^{18}$ The prevalence of the GHR-d3 polymorphism in the Saudi Arabian population and its association with basic anthropometric parameters, such as height and BMI, have not been studied. In this study, the prevalence of this polymorphism in men and women from Saudi Arabia (Jazan province) and the correlations with anthropometric measurements were investigated as a preliminary step for further exploratory studies on the clinical relevance of such polymorphisms in the Saudi population. The findings showed that $39.1 \%$ of subjects

Table 1 - Growth hormone receptor-d3 allele frequencies and HardyWeinberg equilibrium.

\begin{tabular}{lcccc}
\hline Genotypes & Observed & Expected & $\begin{array}{c}\text { HWE } \\
\mathbf{x}^{2}\end{array}$ & $P$-value* \\
\hline $\mathrm{fl} / \mathrm{f}$ & 90 & 87.1 & \\
$\mathrm{fl} / \mathrm{d} 3$ & 103 & 108.9 & 0.67 & 0.41 \\
$\mathrm{~d} 3 / \mathrm{d} 3$ & 37 & 34.1 & \\
\hline \multicolumn{5}{c}{ HWE - Hardy-Weinberg equilibrium } \\
\hline
\end{tabular}

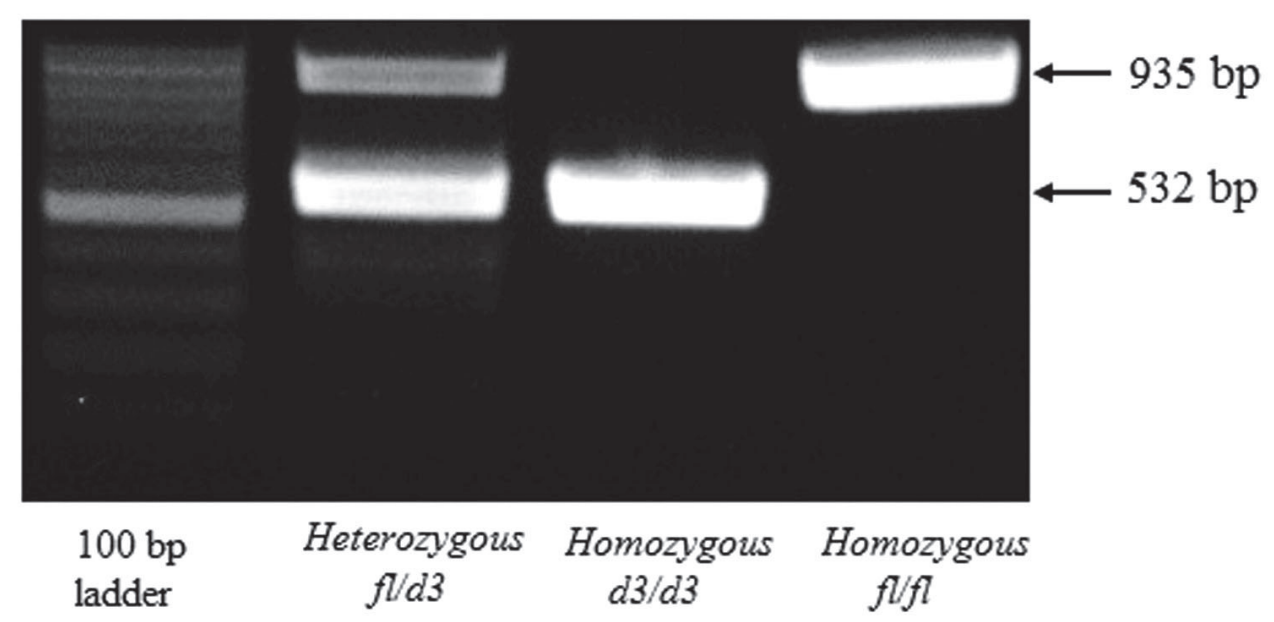

Figure 1 - Polymerase chain reaction products on $1 \%$ agarose gel showing a representative examples of all 3 possible growth hormone receptor (GHR), fl/d3 allelic variants. The homozygous full-length genotype (f/f) indicated by the presence of a single band at $935 \mathrm{bp}$, while the homozygous exon 3 deleted genotype (d3/d3) indicate by the presence of a single band at $532 \mathrm{bp}$. The heterozygous carriers of the full-length and exon 3 deleted genotype $(\mathrm{f} / \mathrm{d} 3)$ represented by the presence of 2 bands at 935 and $532 \mathrm{bp}$. 
carried the GHR-fl/fl genotype, $44.8 \%$ carried the $\mathrm{fl} / \mathrm{d} 3$ genotype, and only $16.1 \%$ carried the homozygous mutated genotype $d 3 / d 3$. The closest country to our overall GHR allelic distributions is Iran, with $\mathrm{fl} / \mathrm{fl}$ of $31 \%, \mathrm{f} / \mathrm{d} 3$ of $49 \%$, and $\mathrm{d} 3 / \mathrm{d} 3$ of $19 \% .{ }^{19}$ As reported in some countries, such as Spain, Benin, and Turkey, we found higher prevalence rates of the GHR $\mathrm{fl} / \mathrm{d} 3$ genotype than the other genotypes. ${ }^{11,20,21}$ However, in some European and western countries, such as the UK, France, Germany, Sweden, Switzerland, and Canada, higher prevalence rates of the GHR $\mathrm{fl} /$ /l genotype have been observed. ${ }^{16,22-26}$ The frequency of the homozygous GHR d3/d3 genotype was $16.1 \%$, which was similar to the average frequencies found in Italy (17.9\%), France (19\%), and Germany (15.2\%). ${ }^{22,23,27}$ Moreover, the highest frequency of the GHR $\mathrm{d} 3 / \mathrm{d} 3$ genotype

Table 2 - Baseline characteristics and the GHR genotypes of the study population $(\mathrm{n}=230)$

\begin{tabular}{lcccc}
\hline Variables & \multicolumn{3}{c}{ GHR genotype } & P-value* \\
& $\mathrm{f} / \mathrm{fl}$ & $\mathrm{fl} / \mathrm{d} 3$ & $\mathrm{~d} 3 / \mathrm{d} 3$ & \\
\hline $\mathrm{n}(\%)$ & $90(39.1)$ & $103(44.8)$ & $37(16.1)$ & - \\
Gender (M/F) & $59 / 31$ & $61 / 42$ & $24 / 13$ & - \\
Age (years) & $33.4 \pm 10.0$ & $31.8 \pm 9.2$ & $36.8 \pm 9.6$ & 0.54 \\
Weight SDS & $-0.03 \pm 0.89$ & $0.03 \pm 1.01$ & $-0.01 \pm 1.20$ & 0.90 \\
Height SDS & $-0.17 \pm 0.98$ & $0.07 \pm 0.88$ & $0.16 \pm 1.22$ & 0.12 \\
BMI SDS & $0.02 \pm 0.88$ & $0.01 \pm 1.06$ & $-0.09 \pm 1.12$ & 0.83 \\
\hline
\end{tabular}

Values are expressed as Mean $\pm S D,{ }^{*}$ One-way Analysis of Variance. SDS - standard deviation score, GHR - growth hormone receptor, BMI - body mass index, $\mathrm{f} / \mathrm{fl}$ - homozygous full-length genotype, $\mathrm{d} 3 /$ $\mathrm{d} 3$ - homozygous exon 3 deleted genotype, $\mathrm{f} / \mathrm{d} 3$ - heterozygous carriers of the full-length and exon 3 deleted genotype was reported in Mexicans (32.4\%), and the lowest was reported in Koreans $(3 \%)^{28,29}$ (Figure 2).

Consistent with several reports, no correlations were observed between the GHR-d3 polymorphism and weight, height, or BMI in this study based on the healthy adult population. ${ }^{16,21,30,31}$ Nevertheless, some studies have revealed an association between the GHR-d3 polymorphism and reduced BMI under some conditions. For example, a Chinese study conducted on obese children reported significant correlations of GHR d3/d3 with low BMI, low insulin resistance, and low total cholesterol. ${ }^{13}$ Similarly, Binder et a ${ }^{14}$ reported a low BMI in patients with Turner's syndrome with homozygous GHR d3/d3 alleles.

The current study has some limitations, including the relatively small sample size compared with the total Saudi Arabian population. Additionally, the study was conducted locally in one region of the country, and samples were collected only from healthy subjects; the GHR-d3 polymorphism has not been linked to some clinical outcomes, such as short stature.

In conclusion, the findings of this study represent the first reported distribution of GHR gene variants among Saudi Arabians. The distributions were 39.1\% for the $\mathrm{fl} / \mathrm{fl}$ genotype, $44.6 \%$ for the $\mathrm{fl} / \mathrm{d} 3$ genotype, and $16.1 \%$ for the $\mathrm{d} 3 / \mathrm{d} 3$ genotype. Consistent with several reports, no correlations were found between the GHR-d3 polymorphism and weight, height, or BMI in this study. However, further studies are required to demonstrate the contribution of the GHR-d3 polymorphism to birth size, BMI, and final height in Saudi Arabians and other Gulf countries.

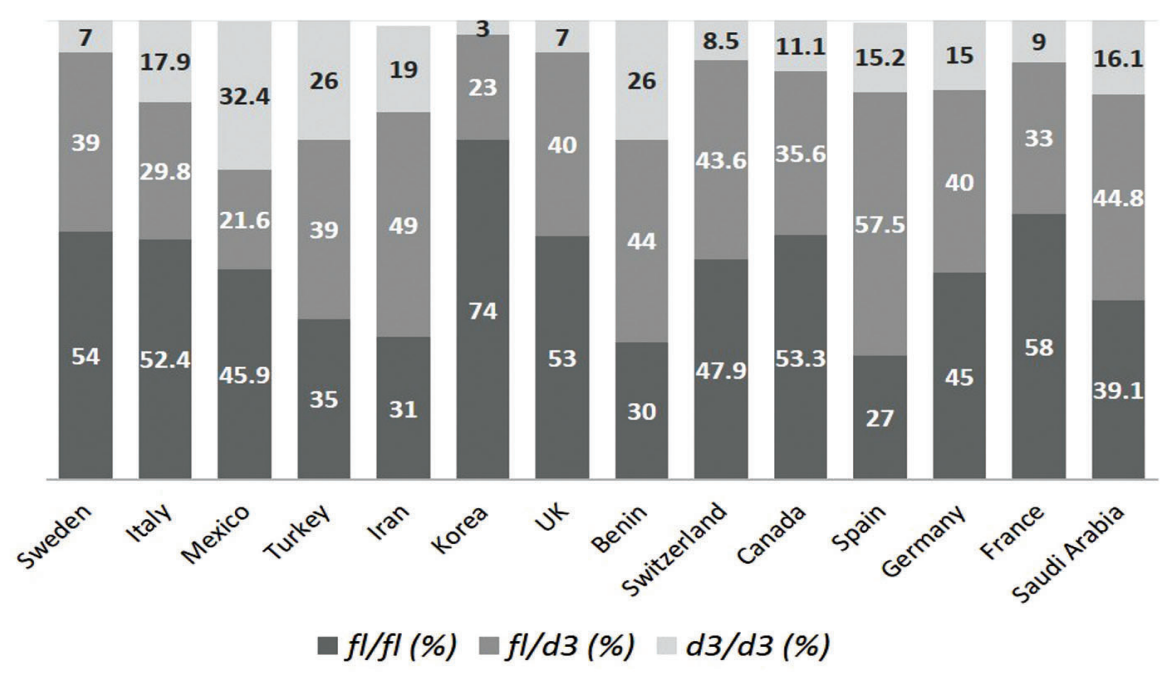

Figure 2 - The frequency of the growth hormone receptor (GHR) exon 3 genotypes in different populations in comparison with the present study in Saudi Arabia. f/fl - homozygous full-length genotype, d3/d3 homozygous exon 3 deleted genotype, $\mathrm{fl} / \mathrm{d} 3$ - heterozygous carriers of the full-length and exon 3 deleted genotype 
Acknowledgment. The author would like to take this opportunity and thank all volunteers who were exceptionally cooperative in the completion of this study. The author would also like to thank the deanship of scientific research at Jazan University, Jazan, Kingdom of Saudi Arabia for moral and financial support.

\section{References}

1. Brooks AJ, Waters MJ. The growth hormone receptor: mechanism of activation and clinical implications. Nat Rev Endocrinol 2010; 6: 515-525.

2. Bazan JF. Structural design and molecular evolution of a cytokine receptor superfamily. Proc Natl Acad Sci US A 1990; 87: 6934-6938.

3. Godowski PJ, Leung DW, Meacham LR, Galgani JP, Hellmiss $\mathrm{R}$, Keret $\mathrm{R}$, et al. Characterization of the human growth hormone receptor gene and demonstration of a partial gene deletion in two patients with Laron-type dwarfism. Proc Natl Acad Sci U S A 1989; 86: 8083-8087.

4. Pantel J, Machinis K, Sobrier ML, Duquesnoy P, Goossens M, Amselem S. Species-specific alternative splice mimicry at the growth hormone receptor locus revealed by the lineage of retroelements during primate evolution. J Biol Chem 2000; 275: 18664-18669.

5. Sobrier ML, Duquesnoy P, Duriez B, Amselem S, Goossens $M$. Expression and binding properties of two isoforms of the human growth hormone receptor. FEBS Letters 1993; 319 (1-2): 16-20.

6. Urbanek M, Russell JE, Cooke NE, Liebhaber SA. Functional characterization of the alternatively spliced, placental human growth hormone receptor. J Biol Chem 1993; 268: 1902519032.

7. Renehan AG, Solomon M, Zwahlen M, Morjaria R, Whatmore A, Audi L, et al. Growth hormone receptor polymorphism and growth hormone therapy response in children: a Bayesian metaanalysis. Am J Epidemiol 2012; 175: 867-877.

8. Audi L, Carrascosa A, Esteban C, Fernandez-Cancio M, Andaluz P, Yeste D, et al. The exon 3-deleted/full-length growth hormone receptor polymorphism does not influence the effect of puberty or growth hormone therapy on glucose homeostasis in short non-growth hormone-deficient small-for-gestationalage children: results from a two-year controlled prospective study. J Clin Endocrinol Metab 2008; 93: 2709-27015.

9. Carrascosa A, Audi L, Fernandez-Cancio M, Esteban C, Andaluz P, Vilaro E, et al. The exon 3-deleted/full-length growth hormone receptor polymorphism did not influence growth response to growth hormone therapy over two years in prepubertal short children born at term with adequate weight and length for gestational age. J Clin Endocrinol Metab 2008; 93: 764-770.

10. Sorensen K, Aksglaede L, Munch-Andersen T, AachmannAndersen NJ, Leffers H, Helge JW, et al. Impact of the growth hormone receptor exon 3 deletion gene polymorphism on glucose metabolism, lipids, and insulin-like growth factor-I levels during puberty. J Clin Endocrinol Metab 2009; 94: 2966-2969.

11. Turgut S, Akin F, Ayada C, Topsakal S, Yerlikaya E, Turgut G. The growth hormone receptor polymorphism in patients with acromegaly: relationship to BMI and glucose metabolism. Pituitary 2012; 15: 374-379.
12. Park HY, Hwang IR, Seo JB, Kim SW, Seo HA, Lee IK, et al. Association between the growth hormone receptor exon 3 polymorphism and metabolic factors in Korean patients with acromegaly. Endocrinol Metab (Seoul) 2015; 30: 312-317.

13. Gao L, Zheng Z, Cao L, Shen S, Yang Y, Zhao Z, et al. The growth hormone receptor (GHR) exon 3 polymorphism and its correlation with metabolic profiles in obese Chinese children. Pediatr Diabetes 2011; 12 (4 Pt 2): 429-434.

14. Binder G, Trebar B, Baur F, Schweizer R, Ranke MB. Homozygosity of the $\mathrm{d} 3$-growth hormone receptor polymorphism is associated with a high total effect of $\mathrm{GH}$ on growth and a low BMI in girls with Turner syndrome. Clin Endocrinol (Oxf) 2008; 68: 567-572.

15. Kang EH, Yamaguchi T, Tajima A, Nakajima T, Tomoyasu Y, Watanabe M, et al. Association of the growth hormone receptor gene polymorphisms with mandibular height in a Korean population. Arch Oral Biol 2009; 54: 556-562.

16. Adetunji OR, MacFarlane IA, Javadpour M, Alfirevic A, Pirmohamed M, Blair JC. The d3/fl-GH receptor gene polymorphism does not influence quality of life and body composition in GH-deficient adults receiving $\mathrm{GH}$ replacement therapy. Eur J Endocrinol 2009; 161: 541-546.

17. Vassiliou G, Rousso I, Katzos G, Vavatsi-Christaki N, Tzimagiorgis G. Correlation of $\mathrm{fl} / \mathrm{d} 3$ polymorphism of growth hormone receptor with the first- and second-year response to recombinant human growth hormone therapy in pre-pubertal Greek children with idiopathic isolated growth hormone deficiency. J Endocrinol Invest 2011; 34: 609-614.

18. Jorge AA, Arnhold IJ. Growth hormone receptor exon 3 isoforms and their implication in growth disorders and treatment. Horm Res 2009; 71 Suppl 2: 55-63.

19. Palizban MR, M Bozorgzad A. Exon 3-deleted and full-length growth hormone receptor polymorphism frequencies in an Iranian population. Res Pharm Sci 2014; 9: 489-494.

20. Audi L, Esteban C, Carrascosa A, Espadero R, Perez-Arroyo A, Arjona R, et al. Exon 3-deleted/full-length growth hormone receptor polymorphism genotype frequencies in Spanish short small-for-gestational-age (SGA) children and adolescents $(\mathrm{n}=247)$ and in an adult control population $(\mathrm{n}=289)$ show increased $\mathrm{Al} / \mathrm{Al}$ in short SGA. J Clin Endocrinol Metab 2006; 91: 5038-5043.

21. Millar DS, Lewis MD, Horan M, Newsway V, Rees DA, Easter TE, et al. Growth hormone (GH1) gene variation and the growth hormone receptor (GHR) exon 3 deletion polymorphism in a West-African population. Mol Cell Endocrinol 2008; 296 (1-2): $18-25$.

22. Kamenicky P, Dos Santos C, Espinosa C, Salenave S, Galland F, Le Bouc Y, et al. D3 GH receptor polymorphism is not associated with IGF1 levels in untreated acromegaly. Eur J Endocrinol 2009; 161: 231-235.

23. Binder G, Baur F, Schweizer R, Ranke MB. The d3-growth hormone $(\mathrm{GH})$ receptor polymorphism is associated with increased responsiveness to $\mathrm{GH}$ in Turner syndrome and short small-for-gestational-age children. J Clin Endocrinol Metab 2006; 91: 659-664.

24. McKay JD, Kaaks R, Johansson M, Biessy C, Wiklund F, Balter $\mathrm{K}$, et al. Haplotype-based analysis of common variation in the growth hormone receptor gene and prostate cancer risk. Cancer Epidemiol Biomarkers Prev 2007; 16: 169-173.

25. Raz B, Janner M, Petkovic V, Lochmatter D, Eble A, Dattani MT, et al. Influence of growth hormone $(\mathrm{GH})$ receptor deletion of exon 3 and full-length isoforms on GH response and final height in patients with severe GH deficiency. J Clin Endocrinol Metab 2008; 93: 974-980. 
26. Kenth G, Shao Z, Cole DE, Goodyer CG. Relationship of the human growth hormone receptor exon 3 genotype with final adult height and bone mineral density. J Clin Endocrinol Metab 2007; 92: 725-728.

27. Bianchi A, Giustina A, Cimino V, Pola R, Angelini F, Pontecorvi A, et al. Influence of growth hormone receptor $\mathrm{d} 3$ and full-length isoforms on biochemical treatment outcomes in acromegaly. J Clin Endocrinol Metab 2009; 94: 2015-2022.

28. Mercado M, Gonzalez B, Sandoval C, Esquenazi Y, Mier F, Vargas G, et al. Clinical and biochemical impact of the $\mathrm{d} 3$ growth hormone receptor genotype in acromegaly. J Clin Endocrinol Metab 2008; 93: 3411-3415.
29. Ko JM, Kim JM, Cheon CK, Kim DH, Lee DY, Cheong WY, et al. The common exon 3 polymorphism of the growth hormone receptor gene and the effect of growth hormone therapy on growth in Korean patients with Turner syndrome. Clin Endocrinol (Oxf) 2010; 72: 196-202.

30. Bas F, Kelesoglu F, Timirci O, Kabatas Eryilmaz S, Bozkurt N, Kucukemre Aydin B, et al. The distribution of exon 3-deleted/ full-length growth hormone receptor polymorphism in the Turkish population. J Clin Res Pediatr Endocrinol 2011; 3: 126-131.

31. Martins CS, Fernandes-Rosa FL, Espineira AR, de Souza RM, de Castro M, Barbieri MA, et al. The growth hormone receptor exon 3 polymorphism is not associated with height or metabolic traits in healthy young adults. Growth Horm IGF Res 2014; 24: 123-129.

\section{Withdrawal policy}

By submission, the author grants the journal right of first publication. Therefore, the journal discourages unethical withdrawal of manuscripts from the publication process after peer review. The corresponding author should send a formal request signed by all co-authors stating the reason for withdrawing the manuscript. Withdrawal of a manuscript is only considered valid when the editor accepts, or approves the reason to withdraw the manuscript from publication. Subsequently, the author must receive a confirmation from the editorial office. Only at that stage, are the authors free to submit the manuscript elsewhere.

No response from the authors to all journal communication after review and acceptance is also considered unethical withdrawal. Withdrawn manuscripts noted to have already been submitted or published in another journal will be subjected to sanctions in accordance with the journal policy. The journal will take disciplinary measures for unacceptable withdrawal of manuscripts. An embargo of 5 years will be enforced for the author and their co-authors, and their institute will be notified of this action. 